\title{
Culture, Medicine, Psychiatry and Wisdom: Honoring Arthur Kleinman
}

\author{
Atwood D. Gaines ${ }^{1}$
}

Published online: 16 November 2016

(C) Springer Science+Business Media New York 2016

It is both a pleasure and an honor to celebrate Dr Arthur Kleinman and his work in this volume year of Culture, Medicine and Psychiatry (2016), the very Journal he founded some 40 years ago while at the University of Washington School of Medicine. Born in New York City, Professor Kleinman is, as most readers know, an anthropologist, Sinologist, ethicist and a psychiatrist. He is Professor (since 1982) and former Chair of Anthropology (2004-2007), Professor (since 1982) and former Chair (1991-2000) of Social Medicine (now Global Health and Social Medicine), Professor of Psychiatry (since 1982) and, until very recently, The Victor and William Fung Director of the Harvard University Asia Center (2008-2016). He is also Board Certified in Psychiatry and Neurology.

Currently, Dr. Kleinman is Professor of Medical Anthropology and Psychiatry in the Department of Global Health and Social Medicine, and Professor of Psychiatry at the Cambridge Hospital. He is the Esther and Sidney Rabb Professor of Anthropology in the Department of Anthropology in the Faculty of Arts and Sciences (FAS), and continues as a member Harvard University's Asia Center. And in 2011, he was named Harvard College Professor. He has been the curator for Medical Anthropology at the Peabody Museum since 1982. From 1992 until 2002, he served as the Presley Professor of Medical Anthropology at Harvard Medical School.

Aside from his academic positions, Professor Kleinman also holds several hospital positions, since 2004 he has been the Senior Medical Anthropologist in the Division of Social Justice and Global Health of the Department of Internal Medicine at the Brigham and Women's Hospital and Psychiatrist at the Cambridge Hospital.

\footnotetext{
Atwood D. Gaines

atwood.gaines@case.edu

1 Case Western Reserve University, Cleveland, OH, USA
} 


\section{Education}

Professor Kleinman is now in his 34th year at Harvard. He is a graduate of Stanford University (1962, with Highest Honors) and Stanford Medical School (1967). He also holds a Master's Degree in social anthropology from Harvard (1974). Trained in psychiatry at the Massachusetts General Hospital, Kleinman is a leading figure in several fields including medical anthropology, cultural psychiatry, global and mental health, social medicine, and medical humanities, the latter in which he has emphasized patient narratives and the ethics of clinical, and other, care as well, and most recently, a search for meaning, specifically, wisdom (cf. Kleinman 2014a, b; 2015a, b).

\section{Fieldwork, Research and Teaching}

He has conducted long term research in China, in Taiwan, from 1969-1970, 1975 and 1977-1978. In addition, he has conducted short-term research during some 22 sojourns in Taiwan, Hong Kong, and other sites in China, as well as a stint in East Africa. In addition, medicine in his home turf was the subject of research from 1983-1986.

His earliest published work focused on biological aspects of neonates (Yang and Kleinman 1970; Yang et al. 1971) and immunological aspects of toxemia (Yang and Kleinman 1974), work rather unknown to his followers today. His widely known research initially focused on the shape of psychiatry in China (1972) and illness experiences, which led to comparisons with US psychiatry and the development of a central critique thereof (Manschreck and Kleinman 1977; Kleinman 1977a, b) as well as its diagnostic entities, especially depression (Good and Kleinman 1995; Kleinman 1977a, b, 1980a, b). Having been concerned with the construction and experience of illness in the 1970s, in 1980 Kleinman produced one of the most influential books in the history of medical anthropology and the social sciences of medicine, his Patients and Healers in the Context of Culture (1980).

This work quickly became the standard text for medical anthropology globally and garnered the Welcome Medal for Medical Anthropology. It provided a number of key and influential theories as well as methodologies for medical anthropology (and other social sciences of medicine). These include the Illness/Disease distinction, the Explanatory Model construct (soon reified and rigidified even by anthropologists) and the dynamics of illness conceptions, the notion of the Local Health Care System, and the Semantic Sickness Network (based on Byron Good's classic, "The Heart of What's the Matter" and his Semantic Illness Network (1976) 1(1) of Culture, Medicine and Psychiatry, it is worth noting).

Arthur Kleinman has solo authored six published books including Patients and Healers. These include, the Social Origins of Distress and Disease, Depression, Neurasthenia and Pain in Modern China, The Illness Narratives, Writing at the Margin; and more recently, What Really Matters. He has also co-written and co- 
edited books on culture and depression; SARS in China; world mental health; suicide; placebos; AIDS in China; and the relationship of anthropology to philosophy (as he probes some of the Ultimate Concerns of life and death). He has produced with his co-authors and co-editors some 33 such volumes in all. Professor Kleinman is currently writing a seventh book on caregiving based on his articles in the Lancet and the New England Journal of Medicine and other venues (e.g., 2014a, b).

Many of his books have focused on policy often closely critiquing accepted theory and or practice with the aim of changing both on the ground (e.g., Cohen et al. 2002; Goldsmith et al. 2002; Petryna et al. 2006; Kaufman et al. 2006).

Of particular importance are his volumes, The Illness Narratives and the Social Origins of Distress and Disease. In these volumes, Kleinman is getting to the crux of the matters of suffering he later considers and the social dimensions of illness, the voices of illness and violence qua chaos in daily life. His work addresses subjectivity and is a clarion call for concern for the inner lives of others. Here, Kleinman is at his most personal as he moves from understanding the experience of social violence and upheaval in others to the constraints of caregiving and the blunt force trauma of loss in his own life (Kleinman 2006, 2014a, b, 2015a, b).

Professor Kleinman's published articles number some 276 since his first publications in 1970. His current fieldwork projects include a comparative study of eldercare for dementia in six Asian settings; an ethnographic study of trust in the doctor-patient relationship in China; and development of Southeast Asia studies at Harvard.

In addition to his vast publication record, Professor Kleinman has amassed a most impressive record of teaching in four units of Harvard University (around 40 different courses) and a heavy burden of mentorship. In regard to the latter, he has produced, as chair, some $75 \mathrm{PhD}$ students (work completed), and $20 \mathrm{MD}-\mathrm{PhD}$ students while serving on innumerable other dissertation committees and guiding several hundred Postdoctoral Fellows and International Fellows. Among his many students, I would be remiss if I did not single out Paul Farmer (MD, PhD Harvard), world-renowned physician and anthropologist to the poor.

As can be gleaned from the above, Professor Kleinman has shouldered the responsibility of chairing three different units of Harvard University, in Anthropology, Social Medicine and the Asia Center. In all, Professor Kleinman has created a stellar career that is yet in full tilt in all of these activities-publishing, teaching, administration and mentoring. The arc of his career has moved from very early concern for biological process to issues of Chinese healing and psychiatry, to studies of Chinese medicine and illness experiences, to the critique of western biomedicine and psychiatry, to formulations to improve and humanize clinical encounters, to the ethics of medicine and of daily life and to life's ultimate questions and the implicated relevance of wisdom. That is, he has developed a focal concern on 'what really matters' as his book title indicated (see Kleinman 2006). His current focus on caring as moral action is part of the larger enterprise, the concern for 'how we endure' the untoward, for we all must, at some point, for ourselves and for others. Kleinman's own words best conclude this all too brief overview of a magisterial body of work and give a flavor of his current interests: 
"Assisting family and professional caregivers as well as patients to endure may not be assessed today as a measure of the cost-effectiveness of healthcare systems, and yet it is at the very core of what human experience is about and what caregiving should be about. Our cultural images today seem blinded to life's limits and dangers. While emphasising human flourishing and celebrating happy outcomes, they obscure the reality of human conditions. Physicians can work hard at achieving the best outcomes, while still acknowledging that their patients, like they themselves, must prepare for lives lived under some degree of constraint. This means that each of us at some point must learn how to endure: the act of going on and giving what we have. And we need, on occasion, to step outside ourselves and look in as if an observer on our endeavours and our relationships-personal and professional - to acknowledge the strength, compassion, courage, and humanity with which we ourselves endure or help to make bearable the hard journeys of others. These are the qualities that make acceptance and striving, if not noble, then certainly deeply human-worthy of respect of ourselves and those whose journeys we share.” (Kleinman 2014b:120). (N.B. UK spelling)

\section{Arthur Kleinman: Awards, Prizes and Honors}

We are able to but mention a very few of the large number of awards, prizes and honors bestowed upon Professor Kleinman in his career. These include the 2016-19 Visiting Professorship at Sun Yat-sen University School of Sociology and Anthropology, the 2015 Fei Xiaotong Memorial Lecture, the 2014 Higgins Lecture, Clark University, a series of lectures in South Africa, and the 2012 Felts Lecture, Flexner Dean's Lecture at Vanderbilt University School of Medicine. In 2011, he was the Magisterial Lecture at the University of Milano (Italy) and the Institute Lecture at the Institut Pasteur (Paris). In that year, he also received the Distinguished Faculty Award from The Harvard Foundation, Harvard University. Professor Kleinman received the George Foster Practicing Medical Anthropology Award from the Society for Medical Anthropology in 2008. 2007 saw him named as the Honorary Professor in the Fudan University, Shanghai, China and as the recipient of the 2007 Medical Humanities Excellence Award from the Imperial College in London. In the previous year, he received the Career Achievement Award from the Society for Medical Anthropology.

The American Psychiatric Association named him the Distinguished Life Fellow in 2005. Other awards of distinction include the 2004 Doubleday Award in Medical Humanities from the University of Manchester, UK and being named, in 2003, Distinguished Fellow of the American Psychiatric Association, prelude to his being awarded the Distinguished Life Fellow by that professional organization. From the American Anthropological Association, CMP's honoree received the Franz Boas Award in 2001. He gave the 1997 William James Lecture at Harvard Divinity School, named for one of his favored scholars and inspirations. His honorary Doctorate (of Science) came in 1996 from York University in Toronto, Canada. In 
that same year, he was awarded the Distinguished Citizen Award from the World Federation of Mental Health.

In 1993-94, he was the Fritz Redlick Fellow at the Center for Advanced Study in the Behavioral Sciences in Palo Alto, California. While in 1993 he was named Honorary Lifetime Fellow in the American Academy on Physician and Patient with 1992 seeing him named Fellow of American Academy of Arts and Sciences. Professor Kleinman is also a Fellow of the John Simon Guggenheim Memorial Foundation (1992) and of the American Psychiatric Association (1985), and of the American Association for the Advancement of Science (1984). Since 1983, he has been a Member of the then Institute of Medicine (now National Academy of Medicine) of the National Academy of Science. He received the Wellcome Medal for Medical Anthropology from the Royal Anthropological Institute in 1980 for his book in that year, Patients and Healers in the Context of Culture. While this list is nearly overwhelming, the reader should be aware that this list omits a large number of lectureships and hundreds of invited talks.

Professor Kleinman's funding has come from a large number of sources, local national and international including, Fogarty Center, NSF, Freeman and the Greenwall, Culpepper and Russell Sage Foundations, and Carnegie Corporation (several), Robert Wood Johnson, MacArthur and Rockefeller Foundations (several), Wenner-Gren (several), NIMH (several), and the Social Science Research Council. He has held a number of consultancies as well.

Our honoree has had a large number of editorial responsibilities for a number of journals including, among many others, Global Public Health, Ethnography, Transcultural Psychiatry Research Review (now Transcultural Psychiatry) Medical Anthropology Quarterly, British Journal of Psychiatry, the Milbank Quarterly as well as being the Founder and Editor-in-Chief of Culture, Medicine and Psychiatry (1976-1986). He has chaired or co-chaired a number of international meetings and served in an advisory capacity for a number of international organizations.

Below, the reader will find the bibliography of Professor Kleinman's work that he has kindly furnished. In this, because of the sheer volume of work in print, we include only published books, articles and chapters. Omitted are his many published reviews, commentaries, prefaces and the like. (See References after bibliography)

\section{Bibliography of Arthur Kleinman}

\section{Books}

1. Kleinman, A. Taking Care: Cares and Caregiving. [In preparation]

2. Kleinman A. 2006. What Really Matters: Living a Moral Life Amidst Uncertainty and Danger. Oxford University Press. Chinese translations published by Shanghai Joint Publishing Company, Shanghai, P.R. China 2007, and by PsyGarden Publishing Company, Taiwan, 2007; Japanese translation published by Seishin Shobo, Tokyo, 2011.

3. Kleinman, A. 1995. Writing at the Margin: Discourse between Anthropology and Medicine. Berkeley: University of California Press. 
4. Kleinman, A. 1988. Rethinking Psychiatry: From Cultural Category to Personal Experience. N.Y.: Free Press.

5. Kleinman, A. 1988. The Illness Narratives: Suffering, Healing and the Human Condition. N.Y.: Basic Books. Japanese translation published by Seishin Shobo, Tokyo; Chinese translations published by Laureate Book Company, Taipei, and by Shanghai Joint Publishing Company, Shanghai, P.R. China 2010.

6. Kleinman, A. 1986. Social Origins of Distress and Disease: Depression and Neurasthenia in Modern China. New Haven: Yale University Press. Chinese translation published by Shanghai Joint Publishing Company, Shanghai, P.R. China, 2008.

7. Kleinman, A. 1980. Patients and Healers in the Context of Culture: An Exploration of the Borderland Between Anthropology, Medicine, and Psychiatry. Berkeley: University of California Press. Awarded the Wellcome Medal for Medical Anthropology, 1980, Royal Anthropological Institute. Japanese translation published by Kobundo, Tokyo.

\section{Multi-authored books}

1. Wilkinson, Iain and Arthur Kleinman. 2015. A Passion for Society: How We Think about Human Suffering. University of California Press.

2. Kleinman, Arthur, Shigeyuki Eguchi, and Akira Kaito. 2015. The Meaning of Providing Care: The Psychology and Medical Anthropology Accompanying the Care of the Ill. Tokyo: Seishinshobo. (In Japanese.)

3. Kleinman, A., Y. Yan, J. Jing, T. Pan, S. Lee, E. Zhang, F. Wu, and J. Guo. 2011. Deep China: The Moral Life of the Person. What Anthropology and Psychiatry Tell Us about China Today. Berkeley: University of California Press.

4. Desjarlais, R., L. Eisenberg, B. Good, and A. Kleinman. 1995. World Mental Health: Problems, Priorities, and Policies in Low-Income Countries. New York: Oxford University Press. Spanish translation published by Pan American Health Organization; Italian translation published by Il Mulino/Alfa Tape, Bologna.

\section{Edited Books}

1. Akyeampong, E., A. G. Hill, and A. Kleinman, eds. 2015. Culture, Mental Illness and Psychiatric Practice in Africa. Indiana University Press.

2. Das, V., M.D. Jackson, A. Kleinman, and B. Singh, eds. 2014. The Ground Between: Anthropologists Engage Philosophy. Durham, NC: Duke University Press.

3. Farmer, P., J. Y. Kim, A. Kleinman, and M. Basilico, eds. 2013. Reimagining Global Health: An Introduction. University of California Press. Korean-language edition published by UC press with T\&H Press.

4. Zhang, E., A. Kleinman, and W. Tu, eds. 2010. Governance of Life in Chinese Moral Experience. The Quest for an Adequate Life. Routledge. 
5. Nie, Jing-Bao, N. Guo, M. Selden, and A. Kleinman, eds. 2010. Japan's Wartime Medical Atrocities: Comparative Inquiries in Science, History, and Ethics. New York: Routledge.

6. Dimsdale, J., X. Yu, A. Kleinman, A., V. Patel, W. Narrow, P. Sirovatka, and D. Regier. 2009. Somatic Presentations of Mental Disorders: Refining the Research Agenda for DSM-V. American Psychiatric Publishing.

7. Biehl, J., B. Good, and A. Kleinman, eds. 2007. Subjectivity: Ethnographic Perspectives. Berkeley: University of California Press.

8. Kaufman, J., A. Kleinman, and A. Saich, eds. 2006. AIDS and Social Policy in China. Cambridge: Harvard University Press.

9. Petryna, A., A. Lakoff, and A. Kleinman, eds. 2006. Global Pharmaceuticals: Ethics, Markets, Practices. Durham, NC: Duke University Press.

10. Kleinman, A. and James L. Watson, eds. 2006. SARS in China: Prelude to a Pandemic? Stanford University Press.

11. Goldsmith, S. K., T.C. Pellmar, A.M. Kleinman, and W.E. Bunney, eds. 2002. Reducing Suicide: A National Imperative. Washington, D.C.: The National Academies Press.

12. Cohen, A., A. Kleinman, and B. Saraceno, eds. 2002. World Mental Health Casebook: Social and Mental Health Programs in Low-Income Countries. New York: Kluwer Academic/Plenum Publishers.

13. Guess, H.A., A. Kleinman, J.W. Kusek, and L.W. Engel, eds. 2002. The Science of the Placebo. London: British Medical Journal Books.

14. Das, V., A. Kleinman, M. Lock, M. Ramphele, and P. Reynolds, eds. 2001. Remaking a World: Violence, Social Suffering, and Recovery. Berkeley: University of California Press.

15. Das, V. and A. Kleinman, eds. 2000. Violence and Subjectivity. Berkeley: University of California Press.

16. Kleinman, A., V. Das, and M. Lock, eds. 2011. Social Suffering. Berkeley: University of California Press 1997. Japanese translation published by UC Press and Misuzu Shobo, Tokyo.

17. Mezzich, J., A. Kleinman, H. Fabrega, and D.L. Parron, eds. 1996. Culture and Psychiatric Diagnosis. Washington, D.C.: American Psychiatric Press.

18. Chen, L., A. Kleinman and N. Ware, eds. 1994. Health and Social Change: An International Perspective. Cambridge: Harvard University Press, Harvard School of Public Health.

19. Chen, L., A. Kleinman and N. Ware, eds. 1992. Advancing Health in Developing Countries: The Role of Social Research. Westport: Auburn House Publishers.

20. Good, M.J., B. Good, P. Brodwin and A. Kleinman, eds. 1992. Pain as Human Experience: An Anthropological Perspective. Berkeley: University of California Press.

21. Becker, J. and A. Kleinman, eds. 1991. Psychosocial Aspects of Depression. Hillsdale: Lawrence Erlbaum.

22. Osterweis, M., A. Kleinman and D. Mechanic, eds. 1987. Pain and Disability: Clinical, Behavioral and Public Policy Perspectives. Washington, D.C.: National Academy Press. 
23. Kleinman, A. and B. Good, eds. 1985. Culture and Depression: Studies in the Anthropology and Cross-Cultural Psychiatry of Affect and Disorder. Berkeley: University of California Press. Japanese translation published by Sogensha, Osaka.

24. Eisenberg, L. and A. Kleinman, eds. 1981. The Relevance of Social Science for Medicine. Dordrecht, Holland: D. Reidel.

25. Kleinman, A. and T.Y. Lin, eds. 1981. Normal and Abnormal Behavior in Chinese Culture. Dordrecht, Holland: D. Reidel. Chinese translation published by Chinese University of Hong Kong Press.

26. Eisdorfer, C., D. Cohen, A. Kleinman and P. Maxim, eds. 1981. Models for Clinical Psychopathology. New York: Spectrum.

27. Kleinman, A., P. Kunstadter, E.R. Alexander and J.L. Gale, eds. 1978. Culture and Healing in Asian Societies: Anthropological. Psychiatric, and Public Health Studies. Cambridge: Schenkman.

28. Manschreck, T.C. and A. Kleinman, eds. 1977. Renewal in Psychiatry. Washington, DC: Hemisphere Publishers, Halsted Press.

29. Kleinman, A., P. Kunstadter, E.R. Alexander and J.L. Gale, eds. 1975. Medicine in Chinese Cultures: Comparative Perspectives. Washington, D.C.: USGPO for Fogarty International Center, N.I.H.

\section{Special Editions of Journals}

1. Good, Byron J., Mary-Jo DelVecchio Good, Sharon Abramowitz, Arthur Kleinman, and Catherine Panter-Brick, guest eds. 2014. "Medical humanitarianism: Research insights in a changing field of practice." Social Science \& Medicine 120: 311-316.

2. Kuah-Pearce, K. E., A. Kleinman, and E. Harrison, guest eds. 2014. "Social Suffering and the Culture of Compassion in a Morally Divided China." Anthropology and Medicine 20(1).

3. Becker, A. and A. Kleinman, guest eds. 2012. Special Anniversary Issue on Global Mental Health. Harvard Review of Psychiatry 20(1).

4. Tucker, J. D., J. Kaufman, J. Bhabha, A. Brandt, and A. Kleinman, guest eds. 2011. "Sex Work in Asia: Health, Agency, and Sexuality." Journal of Infectious Diseases. Volume 204, Supplement 5: S1203-S1240.

5. Stewart, K., G. Keusch, and A. Kleinman. 2010. Special Issue: "Values and Moral Experience in Global Health." Global Public Health 5(2).

6. Kleinman, A., B. Bloom, A. Saich, K. Mason and F. Aulino. 2008. Supplemental Issue: "Avian and Pandemic Influenza: A Biosocial Approach." The Journal of Infectious Diseases Volume 197, Supplement 1: S1-S40.

7. Kleinman, A., B. Bloom, A. Saich, K. Mason and F. Aulino, guest eds. 2008. Special Issue: "Asian Flus in Ethnographic and Political Context: A Biosocial Approach.” Anthropology and Medicine 15(1). 
8. Dimsdale, J., V. Patel, X. Yu, and A. Kleinman, guest eds. 2007. Special Section: "Somatic Presentations of Mental Disorders: Refining the Research Agenda for DSM-V." Psychosomatic Medicine 69(9).

9. Kleinman, A, R. Fox and A. Brandt, guest eds. 1999. "Bioethics and Beyond." Daedalus 128(4).

10. Kleinman, A. and A. Becker, guest eds. 1998. "Cross-Cultural Research." Psychosomatic Medicine 60(4): 389-457.

11. Kleinman, A., V. Das, and M. Lock, guest eds. 1996. "Social Suffering." Daedalus 125(1).

\section{Journals Articles and Book Chapters (grouped by year of publication)}

2016

1. Kleinman, Arthur, Georgia Lockwood Estrin, Shamaila Usmani, Dan Chisholm, Patricio V. Marquez, Tim G. Evans, and Shekhar Saxena. "Time for mental health to come out of the shadows." The Lancet, 387(10035):2274-2275.

2. Aggarwal, Neil Krishan, Kryst Cedeño, Peter Guarnaccia, Arthur Kleinman, and Roberto Lewis-Fernández. "The meanings of cultural competence in mental health: an exploratory focus group study with patients, clinicians, and administrators." SpringerPlus 5(1): 1.

3. Becker, A. E., and A. Kleinman. "Mental Health and the Global Agenda." In Hunter, David J., and Harvey V. Fineberg, eds. Readings in Global Health: Essential Reviews from the New England Journal of Medicine. Oxford University Press, 2015.

4. Freeman, M.C., K. Kolappa, J.M. Caldas de Almeida, A. Kleinman, N. Makhashvili, S. Phakathi, B. Saraceno, G. Thornicroft. "Reversing hard won victories in the name of human rights: a critique of the General Comment on Article 12 of the UN Convention on the Rights of Persons with Disabilities." Lancet Psychiatry. Published online July 6, 2015.

5. Kleinman, A. "An Intellectual Journey and Personal Odyssey." Bulletin of the American Academy of Arts and Sciences. Spring 2015 LXVIII, No. 3, 58-59.

6. Kleinman, A. "Care: in search of a health agenda." The Lancet 386: 240-241.

7. Kleinman, A. "The Search for Wisdom: Why William James Still Matters." In The Ground Between: Anthropologists Engage Philosophy. Das, V., M.D. Jackson, A. Kleinman, and B. Singh, eds. 2014. Durham, NC: Duke University Press. 
8. Das, V., M.D. Jackson, A. Kleinman, B. Singh. "Introduction. Experiments between Anthropology and Philosophy: Affinities and Antagonisms." In The Ground Between: Anthropologists Engage Philosophy. Das, V., M.D. Jackson, A. Kleinman, and B. Singh, eds. 2014. Durham, NC: Duke University Press.

9. Good, Byron J., Mary-Jo DelVecchio Good, Sharon Abramowitz, Arthur Kleinman, and Catherine Panter-Brick. "Medical humanitarianism: Research insights in a changing field of practice." Social Science \& Medicine 120: 311-316.

10. Becker, A. and A. Kleinman. "Cultural psychiatry." In Psychiatry: Past, Present, and Prospect. Sidney Bloch, Stephen A. Green, and Jeremy Holmes, eds. Oxford: Oxford University Press.

11. Westerhaus, M., A. Finnegan, M. Haidar, A. Kleinman, J. Mukherjee, and P. Farmer. "The Necessity of Social Medicine in Medical Education." Academic Medicine [published online ahead of print November 18, 2014]

12. Chen, H., S. Levkoff, and A. Kleinman. "Contextual Knowledge: From Globalization to Global Aging." The Canadian Journal of Sociology 39(1):141158.

13. Kleinman, A. "How We Endure." The Lancet 383(9912):119-120.

14. Kuah-Pearce, K. E., Kleinman, A., and Harrison, E. "Social suffering and the culture of compassion in a morally divided China." Anthropology and Medicine 20(1):1-7.

15. Yang, L.H., F. Chen, K. J. Sia, J. Lam, K. Lam, H. Ngo, S. Lee, A. Kleinman, and B. Good. "'What matters most:' A cultural mechanism moderating structural vulnerability and moral experience of mental illness stigma." Social Science and Medicine 103(February 2014):84-93.

16. Tucker, J.D., J.-B. Nie, Y. Cheng, W. Zhu, and A. Kleinman. "Reviving medicine as the art of humanity in China." The Lancet 383(9927):1462-1463.

17. Kleinman, A. "Implementing Global Mental Health." Depression and Anxiety 30(6):503-505.

18. Kleinman, A. "From Illness as Culture to Caregiving as Moral Experience." The New England Journal of Medicine 368(15):1376-1377.

19. Kleinman, A. "Medical sensibility: whose feelings count?" The Lancet 381(9881):1893-1894.

20. Kleinman, A. "Danger, Subjectivity, and the Chinese Family: Interpersonal processes and the changing political and moral economies of the self." In The Family Model in Chinese Art and Culture. Jerome Silbergeld and Dora C. Y. Ching, eds. Pp. 37-44. Princeton, New Jersey: P.Y. and Kinmay W. Tang Center for East Asian Art.

21. Becker, A. and A. Kleinman. "Mental Health and the Global Agenda." The New England Journal of Medicine 369(1):66-77.

22. Becker, A. and A. Kleinman. "Mental Health and the Global Agenda Reply." The New England Journal of Medicine 369(14):1380-1381. 
23. Kleinman, A. "Culture, Bereavement, and Psychiatry." The Lancet 379(9816):608-609.

24. Becker, A. and A. Kleinman. "An Agenda for Closing Resource Gaps in Global Mental Health: Innovation, Capacity Building and Partnerships." Introduction to Special Anniversary Issue on Global Mental Health, Harvard Review of Psychiatry 20(1):3-5.

25. Kleinman, A. "Medical Anthropology and Mental Health: Five Questions for the Next Fifty Years." In Medical Anthropology at the Intersections: Histories, Activisms, and Futures. Marcia C. Inhorn and Emily A. Wentzell, eds. Pp. 116128. Durham, NC: Duke University Press.

26. Kleinman, A. "Caregiving as moral experience." The Lancet 380(9853):15501551.

27. Patel, V., A. Kleinman, and B. Saraceno. "Protecting the Human Rights of People with Mental Illnesses: A Call to Action for Global Mental Health. In Mental Health and Human Rights: Vision, Praxis and Courage. Michael Dudley, Derrick Silove and Fran Gale, eds. Pp. 362-375. New York: Oxford University Press.

28. Kleinman, A. and G. Ryan: "Images of Things Human: Toward an Ethic of the Making and Interpretation of Ethnographies, Ethnographic Film, and Documentaries." Thammasat University: Thammasat Review Vol.13:5-18.

29. Kleinman, A. "Health, Subjectivity, and Moral Change in China." In The People's Republic of China at 60. Cambridge, MA: Harvard University Asia Center for the Fairbank Center for Chinese Studies (distributed by Harvard University Press).

30. Kleinman, A. "The Divided Self, Hidden Values, and Moral Sensibility in Medicine." The Lancet 377(9768):804-805.

31. Collins, P., V. Patel, S. Joestl, D. March, T. Insel, S. Daar, I. Bordin, E. Costello, M. Durkin, C. Fairburn, R. Glass, W. Hall, Y. Huang, S. Hyman, K. Jamison, S. Kaaya, S. Kapur, A. Kleinman, A. Ogunniyi, A. Otero-Ojeda, MuMing Poo, V. Ravindranath, B. Sahakian, S. Saxena, P. Singer, D.J. Stein, W. Anderson, M. A. Dhansay, W. Ewart, A. Phillips, S. Shurin, and M. Walport. "Grand challenges in global mental health." Nature 475(7354):27-30.

32. Kleinman, A. and B. Hanna. "Religious Values in Global Health." In Ecologies of Human Flourishing. Donald K. Swearer and Susan Lloyd McGarry, eds. Cambridge, Mass: Center for the Study of World Religions, Harvard Divinity School and Harvard University Press.

33. Kleinman, A. "On death and family and anthropology." In Roads and Boundaries: Travels in search of (re)connection. Marian Tankink and Marianne Vysma, eds. Diemen: Uitgeverij AMB.

34. Kleinman, A. “A Search for Wisdom.” The Lancet 378(9803):1621-1622. 
35. Tucker, Joseph D., J. Kaufman, J. Bhabha, and Arthur Kleinman. "Sex Work and Sexually Transmitted Infections in Asia: A Biosocial Analysis." Special issue, "Sex Work in Asia: Health, Agency, and Sexuality." The Journal of Infectious Diseases Volume 204, Supplement 5: S1203-S1205.

36. Kleinman, A. "Four Social Theories for Global Health." The Lancet 375(9725):1518-1519.

37. Kleinman, A. and C. Morgan. "Social science perspectives: a failure of the sociological imagination." In Principles of Social Psychiatry, second edition. C. Morgan and D. Bhugra, eds. Hoboken: John Wiley \& Sons.

38. Kleinman, A. "Caregiving: The Divided Meaning of Being Human and the Divided Self of the Caregiver." In Rethinking the Human. J. Michelle Molina and Donald Swearer, eds., with Susan Lloyd McGarry. Cambridge MA: Center for the Study of World Religions, and Harvard University Press.

39. Kleinman, A. and L. Smith. "Emotional Engagements: Acknowledgement, Advocacy, and Direct Action." In Emotions in the Field: The Psychology and Anthropology of Fieldwork Experience. James Davies and Dimitrina Spencer, eds. Standford, CA: Stanford University Press.

40. Stewart, K. A., G. T. Keusch, and A. Kleinman. "Values and moral experience in global health: Bridging the local and the global." Global Public Health 5(2):115-121.

41. Feierman, S., A. Kleinman, K. Stewart, P. Farmer, and V. Das. “Anthropology, knowledge-flows and global health." Global Public Health 5(2):122-128.

42. Kleinman, A. "Remaking the Moral Person in China: Implications for Health." The Lancet 375(9720):1074-1075.

43. Kleinman, A. "Caregiving: Its Role in Medicine and Society in America and China." Ageing International 35(2):96-108.

44. Kleinman, A. "The Caregiver." In Theory and action. Essays for an anthropologist. Sjeek Van der Geest and Marian Tankink, eds. Diemen: Uitgeverij AMB.

45. Kleinman, A. "Caregiving: The Odyssey of Becoming More Human." The Lancet 373(9660):292-293.

46. Kleinman, A. "Search for a Voice." In Writing on Writing. Writing Across Boundaries. Department of Anthropology, Durham University, UK. Available at http://www.dur.ac.uk/writingacrossboundaries/writingonwriting/

47. Lee, S. and A. Kleinman. "Are Somatoform Disorders Changing with Time?" In Somatic Presentations of Mental Disorders: Refining the Research Agenda for DSM-V. Dimsdale, J., X. Yu, A. Kleinman, V. Patel, W. Narrow, P. Sirovatka, and D. Regier, eds. American Psychiatric Publishing. 
48. Kleinman, A. "Social and cultural anthropology: salience for psychiatry." In New Oxford Textbook of Psychiatry, second edition. Vol. 1. Michael Gelder, N. Andreasen, J. Lopez-Ibor, and J. Geddes, eds. Pp. 275-279. New York: Oxford University Press.

49. Kleinman, A. "Global Mental Health: A Failure of Humanity." The Lancet 374(9690): 603-604.

50. Kleinman, A. and S. van der Geest. " Care' in health care: Remaking the moral world of medicine." Medische Antropologie 21(1):159-168.

51. Kleinman, A. and R. Hall-Clifford. "Stigma: a social, cultural and moral process." Journal of Epidemiology and Community Health 63(6):418-9.

52. Kleinman, A. "Borderlands: professional life lived precariously but happily in anthropology and medicine." Medical Humanities 35(1):6.

53. Kleinman, A. "Catastrophe and Caregiving: The Failure of Medicine as an Art." The Lancet 371(9606):22-23.

54. Kleinman, A., B. Bloom, A. Saich, K. Mason and F. Aulino. "Avian and Pandemic Influenza: A Biosocial Approach." Supplemental Issue, Journal of Infectious Diseases Volume 197, Supplement 1: S1-S40.

55. Kleinman, A., B. Bloom, A. Saich, K. Mason and F. Aulino. "Asian Flus in Ethnographic and Political Context: A Biosocial Approach." Special Issue, Anthropology and Medicine 15(1):1-5.

56. Yang, L.H. and A. Kleinman. "'Face' and the embodiment of stigma in China: The cases of schizophrenia and AIDS." Social Science and Medicine 67(3):398-408.

57. Kleinman, A. “Today's biomedicine and caregiving: are they incompatible to the point of divorce?" Cleveringa Address delivered at the University of Leiden, The Netherlands, 26 November 2007. Available at https://openaccess. leidenuniv.nl/bitstream/handle/1887/19634/oratie\%20Kleinman.pdf?sequence= 2

58. Kleinman, A. and B. Hanna. "Catastrophe, Caregiving and Today's Biomedicine." Biosocieties 3(3):287-301.

59. Abramowitz, S. and A. Kleinman. "Humanitarian intervention and cultural translation: a review of the IASC Guidelines on Mental Health and Psychosocial Support in Emergency Settings." International Journal of Mental Health, Psychosocial Work and Counseling in Areas of Armed Conflict 6(3-4):219-227.

60. Kleinman, A. Specifika biomedicíny, (What is specific to biomedicine, From Kleinman, A. Writing at the Margin.) In Medicína Kontextu Západního Myšlení. Lydie Fialová, Petr Kouba, Martin Špaček, eds. Pp. 120-135. Univerzita Karlova v Praze (Charles University, Prague): Galen. 
61. Yang, L.H., A. Kleinman, B.G. Link, J.C. Phelan, S. Lee, and B. Good. "Culture and stigma: Adding moral experience to stigma theory." Social Science and Medicine 64(7):1524-1535.

62. Lee, D.T.S., J. Kleinman, A. Kleinman. "Rethinking Depression: An Ethnographic Study of the Experiences of Depression Among Chinese." Harvard Review of Psychiatry 15(1):1-8.

63. Lee, S., A. Tsang, X.-Y. Li, M. R. Phillips, and A. Kleinman. "Attitudes Toward Suicide Among Chinese People in Hong Kong." Suicide and LifeThreatening Behavior 37(5):565-575, Health Module.

64. Lee, S. and A. Kleinman. "Are somatoform disorders changing with time? The case of neurasthenia in China." Psychosomatic Medicine 69(9):846-9.

65. Lee, S., M. Chiu, A. Tsang, H. Chui, and A. Kleinman. "Stigmatizing experience and structural discrimination associated with the treatment of schizophrenia in Hong Kong." Social Science and Medicine 62(7):1685-1696.

66. Lee, D., W. Yip, Y. Chen, Q. Meng, and A. Kleinman. "Ethno-psychometric evaluation of the General Health Questionnaire in rural China." Psychological Medicine 36(2):249-255.

67. Keusch, G.T., J. Wilentz, and A. Kleinman. "Stigma and global health: developing a research agenda." The Lancet 367(9509):525-527.

68. Kleinman, A. and P. Benson. "Anthropology in the Clinic: The Problem of Cultural Competency and How to Fix it." PLoS Medicine 3(10):1-4.

69. Kleinman, A. and P. Benson. Alexander Richman Commemorative Lecture: "Culture, Moral Experience and Medicine." The Mount Sinai Journal of Medicine 73(6):834-839.

70. Lee, S., M.T.Y. Lee, M. Chiu, and A. Kleinman. "Experience of social stigma by people with schizophrenia in Hong Kong." British Journal of Psychiatry 186(2):153-157.

71. Kleinman, A. "Culture and Psychiatric Diagnosis and Treatment: What Are the Necessary Therapeutic Skills?" Utrecht, Netherlands: Trimbos-instituut.

72. Lee, S., L. Y. Chan, A.M. Chau, K.P. Kwok, and A. Kleinman, "The experience of SARS-related stigma at Amoy Gardens." Social Science and Medicine 61(9):2038-2046.

73. Kleinman, A. "Tussen lichaam en samenleving: De Sociale en politieke wortels van ziekte en lijden." Cultuur Migratie Gezondheid 2(1).

74. Kleinman, A. and S. Lee. "SARS and the problem of social stigma." In SARS in China: Prelude to Pandemic? A. Kleinman and J.L. Watson, eds. Pp. 173-195. Stanford, CA: Stanford University Press. 
75. Kleinman, A. and P. Benson. "La Vida Moral de los que Sufren Enfermedad y el Fracaso Existencial de la Medicina." In Dolor y Sufrimiento en La Práctica Clínica. Monografías Humanitas 2. Ramón Bayés Sopena, ed. Pp. 17-26. Barcelona: Fundación Medicina y Humanidades Médicas.

76. Kleinman, A. "Culture and Depression." New England Journal of Medicine 351(10):951-953.

77. Kleinman, A. "Ethics and Experience: An Anthropological Approach to Health Equity." In Public Health, Ethics, and Equity. S. Anand, F. Peter, and A. Sen, eds. Pp. 269-282. New York: Oxford University Press.

2003

78. Kleinman, A. "The Moral and the Medical: The Stakes of Social Experience." In Society and Medicine: Essays in Honor of Renée C. Fox. C.M. Messikomer, J. Swazey, and A. Glicksman, eds. New Brunswick, U.S.A. and London: Transaction Publishers.

79. Kleinman, A. "Tehlike, Sinirlilik ve etnografi. Psikoterapik sureclerin Kulturel ve Ahlaki Baglami." In Kultur ve Ruh Sagligi. Kemal Sayer, ed. Pp. 15-32. Istanbul: Metis.

80. Kleinman, A. and J. Kleinman, "Deneyimin Cagrisi, imgelerin dehseti. Gunumuzde Aci Cekmenin Kulturel Belirlenmisligi.” In Kultur ve Ruh Sagligi. Kemal Sayer, ed. Pp. 206-226. Istanbul: Metis.

81. Patel, V. and A. Kleinman. "Poverty and common mental disorders in developing countries." Bulletin of the World Health Organization 81(8):609615.

82. Kleinman A. Introduction: common mental disorders, primary care, and the global mental health research agenda. Harv Rev Psychiatry. 2003 May-Jun; 11(3):155-6.

83. Kleinman, A. "Santé et stigmate. Note sur le danger, l'expérience morale et les sciences socials de la santé." Actes de la recherche en sciences socials 143:9799.

84. Lee, S. and A. Kleinman. "Psychiatry in its political and professional contexts: a response to Robin Munro." The Journal of the American Academy of Psychiatry and the Law 30(1):120-125.

85. Chang, D. and A. Kleinman. "Growing Pains: Mental Health Care in a Developing China." The Yale-China Health Journal 1(1):85-98. 
86. Kleinman, A. and A. Cohen. "A global view of depression from an anthropological perspective." In Depression: social and economic timebomb: strategies for quality care. Proceedings of an international meeting. A. Dawson and A. Tylee, eds. Pp. 11-16. London: British Medical Journal Books for the World Health Organization.

87. Ji, J., A. Kleinman, and A. Becker. "Suicide in Contemporary China: A Review of China's Distinctive Demographics in Their Sociocultural Context." Harvard Review of Psychiatry 9(1):1-12.

88. Kleinman A. "Cross-cultural psychiatry: a psychiatric perspective on global change." Harvard Review of Psychiatry 9(1):46-7.

89. Keshavjee, S., S. Weiser, and A. Kleinman. "Medicine betrayed: hemophilia patients and HIV in the US." Social Science and Medicine 53(8):1081-1094.

90. Petryna, A. and A. Kleinman. "La mondialisation des catégories: la dépression à l'épreuve de l'universel." L'autre: Cliniques, cultures et societies 2(3):467480.

91. Kleinman, A. and A. Petryna. "Health: Anthropological Aspects." In International Encyclopedia of the Social and Behavioral Sciences. N.J. Smelser and Paul B. Baltes, eds. Oxford: Pergamon.

92. Kleinman, A. "Why Psychiatry and Cultural Anthropology Still Need Each Other." Psychiatry 64(1):14-16.

93. Kleinman, A. "Psychiatric disorders: Global findings, local questions." Chinese Journal of Nervous and Mental Disease 26(1):1-5 (English and Chinese).

94. Becker, A.E. and A. Kleinman. "Anthropology and Psychiatry." In Kaplan and Sadock's Comprehensive Textbook of Psychiatry, Volume 1. B.J. Sadock and V.A. Sadock, eds. Pp. 463-475. Philadelphia: Lippincott, Williams and Wilkins.

95. Lee, S. and A. Kleinman. "Suicide as resistance in Chinese society." In Chinese Society: Change, Conflict and Resistance. E.J. Perry and M. Selden, eds. Pp. 221-240. New York: Routledge. Revised and updated in second edition, 2003, pp. 289-311.

96. Lee, S. and A. Kleinman: "Grave new world: Is reform disease or cure for China's mentally ill?" Harvard China Review 2(1):72-75.

97. Kleinman, A. and J. Kleinman. "Lo moral, lo politico y lo medico: Una vision socio-somatica del Sufrimiento." In Psiquiatria Transcultural. Emilio Gonzalez and Josep M. Comelles, eds. Pp. 13-35. Madrid: Asociacion Espanola De Neuropsiquiatria Estudios.

98. Kleinman, A. "Social and Cultural Anthropology: Salience for Psychiatry." In New Oxford Textbook of Psychiatry. M.G. Gelder, J.J. Lopez-Ibor and N. Andreasen, eds. Pp. 300-305. Oxford: Oxford University Press. 
99. Kleinman, A. "From one human nature to many human conditions: An anthropological enquiry into suffering as moral experience in a disordering age." Special Issue: "Current trends in medical anthropology. "Journal of the Finnish Anthropological Society: Suomen Antropologi 24(4).

100. Kleinman, A. "One human nature to many human conditions: An anthropological enquiry into suffering as moral experience in a disordering age." In Developing Anthropological Ideas. The Edward Westermarck Memorial Lectures 1983-1997. Transactions of the Finnish Anthropological Society No. 41. J. Siikala, U. Vuorela, T. Nisula, eds. Pp. 195-215. Helsinki: Valopaino Oy.

101. Kleinman, A. and D. Seeman: "The politics of moral practice in psychotherapy and religious healing." In Tradition, Pluralism, and Identity: In Honour of T.N. Madan. Contributions to Indian Sociology, Occasional Studies 8. Veena Das, Dipankar Gupta, and Patricia Uberoi, eds. Pp. 95-110. New Delhi: Sage Publications.

102. Kleinman, A. and D. Seeman. "Personal experience of illness." In Handbook of Social Studies in Health and Medicine. G.L. Albrecht, R. Fitzpatrick and S. Scrimshaw, eds. Pp. 230-242. Chicago: University of Illinois Press.

103. Kleinman, A. "Ethics and Experience: An Anthropological Approach to Health Equity." Working Paper Series, No. 99.04: Harvard Center for Population and Development Studies, Harvard School of Public Health.

104. Kleinman, A. "The cultural construction of illness experience and behavior: Thought and words." Journal of the Humanities and Social Sciences 37(1):241-272. (Taiwan, in Chinese).

105. Pierce, C.M., F.J. Earls, and A. Kleinman: "Race and culture in psychiatry." In Harvard Guide to Psychiatry. A. Nicholi, ed. Pp. 735-743. Cambridge, MA: The Belknap Press of Harvard University Press.

106. Kleinman, A. "Experience and its moral modes: Culture, human conditions and disorder." In The Tanner Lectures on Human Values. Vol. 20. G.B. Peterson, ed. Pp. 357-420. Salt Lake City: University of Utah Press.

107. Kleinman, A. and J. Kleinman. "The transformation of everyday social experience: What a mental and social health perspective reveals about Chinese communities under global and local change." Culture, Medicine and Psychiatry 23(1):7-24.

108. Kleinman, A., J. Kleinman. and S. Lee. "Introduction to the transformation of everyday social experience in Chinese society: Anthropological, psychiatric and social medicine perspectives." Culture, Medicine and Psychiatry 23(1):16.

109. Mezzich, J., L. Kirmayer, A. Kleinman, H. Fabrega, D. Parron, B. Good, K. Lin, and S. Manson. "The place of culture in DSM-IV." The Journal of Nervous and Mental Disease 187(8):457-464.

110. Kleinman, A. and J. Kleinman. "The moral, the political, and the medical: A sociosomatic view of suffering." In Medicine and the History of the Body: Proceedings of the $20^{\text {th }}, 21^{\text {st }}$ and $22^{\text {nd }}$ International Symposium on the 
Comparative History of Medicine - East and West. Yasuo Otsuka, Shizu Sakai, Shigehisa Kuriyama, eds. Pp. 141-155. Tokyo: Ishiyaku EuroAmerica.

111. Kleinman, A. "Moral experience and ethical reflection: Can ethnography reconcile them? A quandary for 'the new bioethics'." In Special Issue: "Bioethics and Beyond." A. Kleinman, R. Fox and A. Brandt, eds. Daedalus 128(4):69-97.

112. Kleinman, A. "Social violence: Research questions on local experiences and global responses." Archives of General Psychiatry 56(11):978-979.

113. Kleinman, A. and A. Becker. "Sociosomatics': The contributions of anthropology to psychosomatic medicine." In Special Issue: "Cross-Cultural Research." A. Kleinman and A. Becker, guest eds. Psychosomatic Medicine 60(4):389-393.

114. Hicks, M., A. Kleinman, and L. Yang: "The social course of schizophrenia: Local and societal factors." Special Issue: "Schizophrenia: Basic clinical aspects." The Kaohsiung Journal of Medical Sciences 14(7):432-447.

115. Kleinman, A. and A. Cohen. "1997 Mental illness.” Microsoft Encarta 98 Encyclopedia. Redmond, WA: Microsoft.

116. Manson, S.M. and A. Kleinman. "DSM-IV, culture and mood disorders: A critical reflection on recent progress." Transcultural Psychiatry 35(3):377386.

117. Kleinman, A. and A. Cohen: "Psychiatry's global challenge." Scientific America 276(3):86-89.

118. Kleinman, A. "Triumph or pyrrhic victory? The inclusion of culture in DSMIV." Harvard Review of Psychiatry 4(6):343-344.

119. Kleinman, A. and J. Kleinman. "Moral transformations of health and suffering in Chinese society." In Morality and Health. A. Brandt and P. Rozin, eds. New York: Routledge.

120. Kleinman, A. "'Everything that really matters:' Social suffering, subjectivity, and the remaking of human experience in a disordering world." Harvard Theological Review 90(3):315-335.

121. Mezzich, J.E., A. Kleinman, H. Fabrega, D.L. Parrone, B. Good, K.M. Lin, and S.M. Manson. "Cultural Issues for DSM-IV." In DSM-IV Sourcebook, Volume 3. Thomas A. Widiger, Allen J. Frances, Harold Alan Pincus, and Ruth Ross, eds. Pp. 861-866. Washington, D.C.: American Psychiatric Publishing.

122. Kleinman, A., D.L. Parrone, H. Fabrega, B. Good, and J.E. Mezzich. "Culture in DSM-IV." In DSM-IV Sourcebook, Volume 3. Thomas A. Widiger, Allen J. Frances, Harold Alan Pincus, and Ruth Ross, eds. Pp 867-873. Washington, D.C.: American Psychiatric Publishing. 
123. Desjarlais, R. and A. Kleinman. "Violence and well-being." Social Science and Medicine 45(8):1143-1145.

124. Cohen, A., P. Farmer, and A. Kleinman. "Health-behavior interventions. With whom?" Forum:"What are the limits to health intervention?" Health Transition Review 7(1):81-85.

125. Jenkins, R., M. de Vries, L. Eisenberg, A. Kleinman. "WHO: where there is no vision, the people perish." The Lancet 350(9089):1480.

126. Eisenberg L., A. Kleinman, A. Cohen. "Child and adolescent mental health: a global perspective." Journal of Child and Adolescent Psychiatric Nursing 10(3):9-10.

127. Kleinman, A. "Intimations of solidarity? The popular culture responds to assisted suicide." Hastings Center Report 27(5):34-36

128. Lee S. and A. Kleinman. "Mental illness and social change in China." Harvard Review of Psychiatry 5(1):43-46.

129. Levkoff, S., W.L. Hinton, J. Simmons, M. Lam, M. Hicks, Z. Guo, J. Hillygus, R. Dunigan, B. Lui, H. Reynoso, B. Levy, S. Fung, A. Kleinman. "A Qualitative Analysis of Dementia Explanatory Models Across Four Ethnic Groups." In Alzheimer's Disease: Biology, Diagnosis, and Therapeutics. K. Iqbal, B. Winblad, T. Nishimura, M. Takeda, H.M. Wisniewski, eds. Pp. 799-804. John Wiley \& Sons.

130. Hinton, W.L. and A. Kleinman. "Cultural Issues in Primary Care Medicine." In Primary Care Medicine. J. Noble, H. Green, J. Heffernan, W. Levinson, G. Modest, eds. CD-ROM, Mosby-Yearbook.

131. Kleinman, A. "How culture is important for DSM-IV." In J. Mezzich et al., eds. Culture and Psychiatric Diagnosis. Washington, D.C.: American Psychiatric Press.

132. Kleinman, A. "Suffering in China and the West: The challenge of an interpersonal locus of experience to the hypertrophy of individual autonomy in health." In Coping with Sickness: Perspectives on Health Care, Past and Present. J. Woodward and R. Jutte, eds. Pp. 43-52. History of Medicine, Health and Disease Series. Sheffield: European Association for the History of Medicine and Health Publications.

133. Kleinman, A. "Suffering." In Blackwell Dictionary of Anthropology. T. Barfield, ed. Cambridge, MA: Basil Blackwell.

134. Kleinman, A. "Sociosomatics: How the social world affects bodily processes." Psychiatria et Neurologia Japonica 98(8):523-532.

135. Kleinman, A. "Bordieu's impact on the anthropology of suffering." In Special Issue: "Bourdieu's Thought." M'hammed Sabour and Loïc J.D. Wacquant, eds. International Journal of Contemporary Sociology 33(2):203-209.

136. Kleinman, A. "The good death: Is it compatible with global culture and biomedicine?" The Maine Scholar 9(6):1-8. 
137. Cohen, A., A. Kleinman, and R. Desjarlais. "Untold casualties: Mental health and the violence epidemic." Harvard International Review 18(4):12-15.

138. Kleinman, A. and J. Kleinman. "The appeal of experience, the dismay of images." Daedalus 125(1):1-23.

139. Kleinman A. "Suffering, ethics, and the politics of moral life." Culture, Medicine and Psychiatry 20(3):287-90.

140. Kleinman A., A. Seymour, and A. Cohen. "World mental health: needs and resources Behavioral Health Tomorrow 5(4):28-31, 88-92.

141. Kleinman, A. "Anthropology of Bioethics." In Encyclopedia of Bioethics, revised edition. W.T. Reich, et al., eds. Pp. 1667-1674. New York: Macmillan. Library Reference USA, Simon \& Schuster Macmillan. Revised version reprinted in A. Kleinman: Writing at the Margin: Discourse Between Anthropology and Medicine Berkeley: University of California Press, 1995.

142. Kleinman, A., W.Z. Wang, S.C. Li, X.M. Cheng, X.Y. Dai, and J. Kleinman. "The social course of epilepsy: Chronic illness as social experience in interior China." Social Science and Medicine 40(10):1319-1330.

143. Kleinman A., and J. Kleinman. "Remembering the Cultural Revolution: Alienating pains and the pains of alienation/transformation." In Chinese Societies and Mental Health. T.Y. Lin, Wen-Shing Tseng, Yingkun Ye, eds. Pp. 141-155. Hong Kong: Oxford University Press,

144. Lewis-Fernandez, R., and A. Kleinman. "Cultural psychiatry: Theoretical, clinical, and research issues." The Psychiatric Clinics of North America 18(3):433-448.

145. Johnson, T., E. Hardt, and A. Kleinman. "Cultural factors in medical interviews." In The Medical Interview: Clinical Care, Education, Research. M. Lifkin, Jr., S.M. Putnam, and A. Lazare, eds. Pp. 153-162. New York: Springer-Verlag.

146. Kleinman, A. "The social course of chronic illness: Delegitimation, resistance and transformation in North American and Chinese societies." In Chronic Illness: From Experience to Policy. S.K. Toombs, D. Barnard and R. Carson, eds. Pp. 176-188. Bloomington: Indiana University Press.

147. Kleinman, A. "Pitch, picture, power: The globalization of local suffering and the transformation of social experience. An essay in honor of Veena Das." ETHNOS: Journal of the National Museum of Ethnography, Stockholm 60(34):181-191.

148. Kleinman, A. "Mental health in low-income countries." Harvard Review of Psychiatry 3(4):235-239.

149. Kleinman, A. and L. Eisenberg. "Mental health in low-income countries." Nature-Medicine 1(7) 630-631.

150. Kleinman, A. "Building the workforce for a diverse society." In Proceedings of the $3^{\text {rd }}$ Congress of Health Professions Educators. E. Rubin, ed. Association of Academic Health Centers. 
151. Lewis-Fernandez, R. and A. Kleinman: "Culture, personality, and psychopathology." Journal of Abnormal Psychology 103(1):67-71.

152. Kleinman, A. and J. Kleinman. "How bodies remember: Social memory and bodily experience of criticism, resistance and delegitimation following China's Cultural Revolution.” New Literary History 25(3):707-723.

153. Kleinman, A. "An anthropological perspective on objectivity: Observation, categorization and the assessment of suffering." In Health and Social Change: An International Perspective. Series on Population and International Health, Harvard School of Public Health: Harvard University Press.

154. Xiong, W., Phillips, M.R., Hu, X., Wang, R., Dai, Q.Q., Kleinman, A., and J. Kleinman. "Family based intervention for schizophrenic patients in China: A randomized controlled trial." British Journal of Psychiatry 165:239-247.

155. Desjarlais, R. and A. Kleinman. "Violence and demoralization in the new world order." Anthropology Today 10(5):9-12.

156. Kleinman, A. and R. Desjarlais. "Ni patients ni victimes: Pour une ethnographie de la violence politique." Actes de la recherche en sciences sociales 104(1):56-63.

157. Hinton, W. L, IV and A. Kleinman. "Cultural issues and international diagnosis." In International Review of Psychiatry. J. A. Costa-e-Silva and C. C. Nadelson, eds. APA Press, Washington, D.C.

158. Kleinman, A. "What is specific to Western Medicine?" In Encyclopedia of the History of Medicine. W. Bynum and R. Porter, eds. Pp. 15-23. New York: Routlege.

159. Kleinman, A. and J. Kleinman. "Face, favor, and families: The social course of mental health problems in Chinese and American societies." Chinese Journal of Mental Health 6:37-47. (Taiwan)

160. Kleinman, A. "Pain and resistance. The delegitimation and relegitimation of local worlds." Pain as Human Experience: An Anthropological Perspective. In M.J.D. Good, P.E. Brodwin, and B.J. Good, eds. Pp. 169-197. Berkeley: University of California Press.

161. Sugar, J., A. Kleinman, and L. Eisenberg. "Psychiatric morbidity in developing countries and American psychiatry's role in international health." Hospital and Community Psychiatry 43(4):355-361.

162. Kleinman, A. "Local worlds of suffering: An interpersonal focus for ethnographies of illness experience." Qualitative Health Research 2(2):127134. 
163. Ware, N. and A. Kleinman. "Depression in Neurasthenia and Chronic Fatigue Syndrome." Psychiatric Annals 22(4):202-208.

164. Christakis, N., A. Kleinman and N. Ware. "An anthropological approach to social science research on the health transition." In Advancing Health in Developing Countries: The Role of Social Science Research. L. Chen, N. Ware, A. Kleinman and J. Potter, eds. Pp. 23-38. Westport, CT: Auburn House.

165. Ware, N. and A. Kleinman. "Culture and somatic experience: the social course of illness in Neurasthenia and Chronic Fatigue Syndrome." Psychosomatic Medicine 54(5):546-560.

166. Jenkins, J., A. Kleinman, and B. Good. "Cross-cultural studies of depression." In Psychosocial Aspects of Depression. J. Becker and A. Kleinman, eds. Pp. 67-99. New York: Earlbaum.

167. Kleinman, A. "Suffering, healing and the human condition." Encyclopedia of Human Biology. Renato Dulbecco, ed. New York: Academic Press.

168. Kleinman, A. and J. Sugar. "Whither culture in a biological era in psychiatry?" Special Issue: "Essays in Honor of Harry Hoijer." Medical Anthropology Lecture Series. Anthropology UCLA Spring: 20-42.

169. Sugar, J., A. Kleinman, and K. Heggenhougen. "Development's 'downside': Social and psychological pathology in countries undergoing social change." Health Transition Review 1(2):91.

170. Kleinman, A. and J. Kleinman. "Suffering and its professional transformation: Towards an ethnography of interpersonal experience." Culture, Medicine and Psychiatry 15(3):275-301. Reprinted in Things as They Are: Readings in the Anthropology of Experience. Michael Jackson, ed. Pp. 169-195. Bloomington: Indiana University Press.

171. Csordas, T. and A. Kleinman. "The therapeutic process." In Medical Anthropology: Contemporary Theory and Method. T. Johnson and C. Sargent, eds. Pp.11-25. New York: Praeger. Revised version in second edition, 1996. Italian translation published in Medicina, magia, religione, valori: Dall'etnopsichiatria. Lanternari, V. and L. Ciminelli, eds. Pp. 109-130 Naples: Liguori Editore, Vol. 1998.

172. Guarnaccia, P.J., B. Good and A. Kleinman. "A critical review of epidemiological studies of Puerto Rican mental health." American Journal of Psychiatry 147(11):1449-1456. 
173. Kleinman, A. "The sources of pain, distress, and misery: A medical anthropological perspective on the symbolic bridge between social structure and physiology." Kroeber Anthropological Society Papers 69-70:14-22.

174. Kleinman, A. "A better balance for basic sciences." In Postgraduate Training in Psychiatry: Options for International Collaboration. N. Holden and G. Edwards, eds. Pp. 21-25. Geneva: World Health Organization.

175. Kleinman, A. "Culture as autognosis: An outer journey toward the self." In Autognosis: How Psychiatrists Analyze Themselves. E. Messner et al., eds. Pp. 101-113. Chicago: Year Book Medical Publishers.

176. Farmer, P. and A. Kleinman. "AIDS as human suffering." Daedalus 118(2):135. Reprinted in Living With AIDS, Stephen Graubard, ed., Cambridge: MIT Press, 1990. Reprinted in Applying Cultural Anthropology, second edition, A. Podolefsky and P. Brown, eds. Mountain View: Mayfield Press, 1993. Reprinted in Applying Anthropology, third edition, A. Podolefsky and P. Brown, eds. Mountain View: Mayfield Press, 1994.

177. Jou, S.Y., J.K. Wen, A. Kleinman, J. Kleinman, Y. Wu, C.C. Chin and M. Schiller. "A pilot study of expressed emotion of relatives of patients with schizophrenia in Taiwan." Chinese Psychiatry, Supplement 1(3):124-137.

178. Kleinman, A. "A window on mental health in China." American Scientist 76(1):22-27.

179. Kleinman, A. "Medical anthropology at Harvard: From culture to experience." Symbols 12:2-4.

180. Lin, K.M. and Kleinman, A. "Psychopathology and the clinical course of schizophrenia: A cross-cultural perspective." Schizophrenia Bulletin 14(4):555-567.

181. Kleinman, A. "Potential for anthropology in medicine." Life Science 15(3):617. (In Japanese.)

182. Kleinman, A. "Symptoms of relevance, signs of suffering: The search for a theory of illness meanings." Semiotica 65(1/2):163-174.

183. Kleinman, A. "Culture and clinical reality: commentary on culture-bound syndromes and international disease classifications." Culture, Medicine and Psychiatry 11:49-52.

184. Weiss, M., and A. Kleinman, "Psychosocial and cross-cultural issues in depression: A prolegomenon for culturally informed research." In Psychology, Culture and Health: Toward Applications. P. Dassen, N. Sartorius, et al., eds. Beverly Hills: Sage. 
185. Brodwin, P. and Kleinman, A. "The social aspects of chronic pain." In Handbook of Chronic Pain Management. Burrows, G., ed. Pp. 109-120. Amsterdam: Elsevier.

186. Kleinman, A. "Anthropology and psychiatry: The role of culture in crosscultural research on illness." British Journal of Psychiatry 151(4):447-454.

187. Kleinman, A. "Some uses and misuses of social science in medicine." In Methodology in Social Science. Fiske, D. and R. Shweder, eds. Pp. 222-245. Chicago: University of Chicago Press.

188. Kleinman, A. "Interpreting illness meanings." Medical Encounter 3(3):5-7.

189. Kleinman, A. "Understanding the impact of illness on the individual and the family." Journal of Psychosocial Nursing and Mental Health Services 24(4):33-6.

190. Kleinman, A. "Not by the doctor-patient relationship alone." Integrative Psychiatry 4:9-10.

191. Kleinman, A. Culture, quality of life and cancer pain. In Assessment of Quality of Life and Cancer Treatment: Proceedings of the International Workshop on Quality of Life Assessment and Cancer Treatment, Milan, 11-13 December 1985. Vittorio Ventafridda and World Health Organization, eds. Pp. 43-50. Amsterdam: Elsevier.

192. Kleinman, A. "Social origins of distress and disease: Depression, neurasthenia, and pain in modern China." Current Anthropology 27(5):499-509.

193. Kleinman, A. "Anthropology and psychiatry: The role of culture in crosscultural research in illness." In Psychiatry and Its Related Disciplines: The Next Twenty-Five Years. Raben Rosenberg, Fini Schulsinger, and Erik Stromgre, eds. Pp. 143-160. Copenhagen: World Psychiatry Association.

194. Kleinman, A. "Illness meanings and illness behavior." In Illness Behavior: A Multi-disciplinary Model. S. McHugh and T.M. Vallis, eds. Pp. 149-160. New York: Plenum.

195. Kleinman, A. "Interpreting illness experience and clinical meanings: How I see clinically applied anthropology." Medical Anthropology Quarterly 16(3):69-71.

196. Lin, E.H.B., W. Carter and A. Kleinman. "An exploration of somatization among Asian refugees and immigrants in primary care." Journal of Public Health 75(9):1080-1084.

197. Kleinman, A. and J. Kleinman. "Somatization: Interconnections among Chinese culture, depressive meanings and the experience of pain." In Culture and Depression: Studies in the anthropology and cross-cultural psychiatry of affect and disorder. A. Kleinman and B. Good, eds. Pp. 429-490. Berkeley: University of California Press. 
198. Good, B., and Kleinman, A. "Culture and anxiety: Cross-cultural evidence for the patterning of anxiety disorders." In Anxiety and the Anxiety Disorders. A.H. Tuma and J.P. Maser, eds. Pp. 297-324. Hillsdale, N.J.: Lawrence Earlbaum.

199. Kleinman, A. “Somatization.” Referential Journal of Psychiatry 11(2):65-68. (People's Republic of China, in Chinese.)

200. Kleinman, A. "Clinically applied medical anthropology: The view from the clinic." In Advances in Medical Social Science, Volume 2. J. Rumni, ed. Pp. 269-288. New York: Gordon and Breach Science Publishers.

201. Katon, W., R. Ries, and A. Kleinman. "The prevalence of somatization in primary care." Comprehensive Psychiatry 25(2):208-215.

202. Katon, W., R. Ries, and A. Kleinman. "A prospective DSM-III study of 100 consecutive somatization patients." Comprehensive Psychiatry 25(3):305-314.

203. Kleinman, A. "Medical anthropology." In The Social Science Encyclopedia. A. Kuper and J. Kuper, eds. London: Routledge \& Kegan Paul.

204. Kleinman, A. et al. "Sociocultural processes." In Bereavement: Reactions, Consequences and Care. Marian Osterweis, Fredric Solomon, and Morris Green, eds. Pp. 199-214. Washington, DC: National Academy of Sciences Press.

205. Johnson, T. and A. Kleinman. "Cultural concerns in psychiatric consultation." In Manual of Psychiatric Consultation and Emergency Care. Frederick G. Guggenheim and Myron F. Weiner, eds. Pp. 275-284. New York: Jason Aronson.

206. Kleinman, A. "Indigenous systems of healing: Questions for professional, popular and folk care." In Alternative Medicines: Popular and Policy Perspectives. J.W. Salmon, ed. Pp. 138-164. London: Tavistock.

207. Kleinman, A. "The cultural meanings and social uses of illness behavior: A role for medical anthropology and clinically oriented social science in the development of primary care theory and research." Journal of Family Practice 16(3):539-545.

208. Smith, C.K. and A. Kleinman. "Beyond the biomedical model." In Family Medicine: Principles and Practice, second edition. R. B. Taylor, J. Buckingham, E.P. Donatelle, E.W. Jacott, and M. G. Rosen, eds. Pp. 88-96. SpringerVerlag.

209. Chrisman, N. and A. Kleinman. "Popular health care and lay referral networks." In Handbook of Health, Health Care, and Health Professions. D. Mechanic, ed. New York: The Free Press.

210. Hahn, R. and A. Kleinman. "Biomedical practice and anthropological theory: Frameworks and directions." Annual Review of Anthropology 12:305-333. 
211. Hahn, R. and A. Kleinman. "Belief as pathogen, belief as medicine: "Voodoo death' and the 'placebo phenomenon' in anthropological perspective." Medical Anthropology Quarterly 14(4):16-19.

212. Rosen, G. and A. Kleinman. "Social science in the clinic: Applied contributions from anthropology to medical teaching and patient care." In Behavioral Sciences in the Practice of Medicine. J. Carr and J. Demgeroml, eds. Pp. 85-104. New York: Elsevier Science.

213. Katon, W., A. Kleinman and G. Rosen. "Depression and somatization: A review, Part I and Part II." American Journal of Medicine 72(1):127-135 and 72(2):241-247.

214. Lin, K.M., T.S. Inui, A. Kleinman, and W.M. Womack. "Sociocultural determinants of the help-seeking behavior of patients with mental illness." The Journal of Nervous and Mental Disease 170(2):78-85

215. Rosen, G., A. Kleinman, W. Katon. "Somatization in family practice: A biopsychosocial approach." Journal of Family Practice 14(3):493-502.

216. Kleinman, A. "Neurasthenia and depression: A study of somatization and culture in China." Culture, Medicine and Psychiatry 6(2):117-189.

217. Kleinman, A. "Cultural issues affecting clinical investigation in developing societies." In Cashiers de Bioéthique. Vol. 4: Médecine et Expérimentation. Pp. 341-358. Quebec: Les Presses de L'Université Laval.

218. Kleinman, A. "Medicalization and the clinical praxis of medical systems." In The Use and Abuse of Medicine. M. de Vries, R.L. Berg and M. Upkin, Jr., eds. Pp. 42-49. Praeger Scientific.

219. Kleinman, A. "The teaching of clinically applied medical anthropology on a psychiatric consultation-liaison service." In Clinically Applied Anthropology. N. Chrisman and T. Maretzki, eds. Pp. 83-115. Dordrecht, Holland: D. Reidel.

220. Beitman, B.D., H. Featherstone, L. Kastner, W. Katon, and A. Kleinman. "Steps toward patient acknowledgement of psychosocial factors." Journal of Family Practice 15(6):1119-26.

221. Beitman, B., H. Featherston, L. Kastner, W. Katon and A. Kleinman. "Steps toward patient acknowledgment of psychosocial factors." Journal of Family Practice 15(6):1119-1126.

222. Kleinman, A. and J. Gale. "Patients treated by physicians and folk healers: A comparative outcome study in Taiwan." Culture, Medicine and Psychiatry 6(4):405-423.

223. Kleinman, A. "The meaning context of illness and care: Reflections on a central theme in the anthropology of medicine." In Special Issue: "Sciences and Cultures: Anthropological and Historical Studies of the Sciences." E. 
Mendelsohn and Y. Elkana, eds. Sociology of the Sciences: A Yearbook 5:161176.

224. Kleinman, A. "On illness meanings and clinical interpretation: not 'rational man', but a rational approach to man the sufferer/man the healer." Culture, Medicine and Psychiatry 5(4):373-7.

225. Smilkstein, G., A. Kleinman, N. Chrisman, G. Rosen and W. Katon. "Clinical social science conference: A biopsychosocial teaching instrument." Journal of Family Practice 12(2):347-353.

226. Lin, Keh-Ming and A. Kleinman. "Recent development of psychiatric epidemiology in China." Culture, Medicine and Psychiatry 5(1):135-144.

227. Ries, R., J. Borkan, W. Katon and A. Kleinman. "The medical care abuser: Differential diagnosis and management." Journal of Family Practice 13(2): 257-265.

228. Kleinman, A. "Culture for psychiatry: Comments on Maretzki's 'the culture paradigm.'” In Conceptual Models for Psychopathology. C. Eisdorfer, D. Cohen, A. Kleinman, and P. Maxim, eds. New York: Spectrum.

229. Kleinman, A. "Culture and patient care: Psychiatry among the Chinese." Drug Therapy 11(11) 134-140.

230. Mechanic, D. and A. Kleinman. "Ambulatory medical care in the People's Republic of China: An exploratory survey." American Journal of Public Health 70(1):62-66.

231. Kleinman, A. "Ethnicity and clinical care: The Chinese patient." Physician Assistant \& Health Practitioner 4(1): 60-68. Republished in Hospital Physician 7:58-71, 1982.

232. Kleinman, A. "Indigenous and traditional systems of healing." In Health for the Whole Person. A. C. Hastings, J. Fadiman, and J.S. Gordon, eds. Pp. 427442. Boulder, Colorado: Westview Press.

233. Chrisman, N. and A. Kleinman. "Health beliefs of American ethnic groups." In Harvard Encyclopedia of American Ethnic Groups. S. Themstrom, A. Orlov, O. Handlin, eds. Pp. 452-462. Cambridge: Belknap Press of Harvard University Press.

234. Kleinman, A. and G. Smilkstein. "Psychosocial issues in assessment in primary care." In Behavioral Science in Family Practice. G.M. Rosen, J.P. Geyman, and R.H. Layton, eds. Pp. 95-108. New York: Appleton-CenturyCrafts.

235. Lin, K.M., A. Kleinman and T.Y. Lin. "Psychiatric epidemiology in Chinese cultures: An overview." In Normal and Abnormal Behavior in Chinese Culture. A. Kleinman and T.Y. Lin, eds. Pp. 237-271. Dordrecht, Holland: D. Reidel.

236. Kleinman, A. and D. Mechanic. "Mental illness and psychosocial aspects of medical problems in China." In Normal and Abnormal Behavior in Chinese 
Culture. A. Kleinman and T.Y. Lin, eds. Pp. 331-355. Dordrecht, Holland: D. Reidel.

237. Katon, W. and A. Kleinman. "A biopsychosocial approach to surgical evaluation and outcome." Western Journal of Medicine 133:9-14.

238. Eisenberg, L. and A. Kleinman. "Clinical social science." In The Relevance of Social Science for Medicine. L. Eisenberg and A. Kleinman, eds. Pp. 1-23. Dordrecht, Holland: D. Reidel.

239. Katon, W. and A. Kleinman. "Clinical social science interventions in primary care: A review of doctor-patient negotiation and other relevant social science concepts and strategies." In The Relevance of Social Science for Medicine. L. Eisenberg and A. Kleinman, eds. Pp. 253-278. Dordrecht, Holland: D. Reidel.

240. Katon, W., R. Ries, J. Borkan and A. Kleinman. "Hyperemesis gravidarum: A biopsychosocial perspective." The International Journal of Psychiatry in Medicine 10(2):151-162.

241. Reis, R., J. Borkan, A. Kleinman and M. Schuckit. "Psychiatric consultationliaison service: Patients, request, and functions." General Hospital Psychiatry 2(3):204-212

242. Kleinman, A. "Traditional medicine in China." In Rural health in the People's Republic of China: Report of a Visit by the Rural Health Systems Delegation, June 1978. Committee on Scholarly Communication with People's Republic of China. Pp. 63-74. Washington, D.C.: Fogarty International Center.

243. Kleinman, A. and D. Mechanic. "The treatment of mental illness in China." In Rural health in the People's Republic of China: Report of a Visit by the Rural Health Systems Delegation, June 1978. Committee on Scholarly Communication with People's Republic of China. Pp. 141-161. Washington, D.C.: Fogarty International Center.

244. Mechanic, D. and A. Kleinman. "The organization, delivery, and financing of rural medical care in the People's Republic of China." In Rural health in the People's Republic of China: Report of a Visit by the Rural Health Systems Delegation, June 1978. Committee on Scholarly Communication with People's Republic of China. Pp. 17-22. Washington, D.C.: Fogarty International Center.

245. Mechanic, D. and A. Kleinman. "Patient self-care and utilization of ambulatory medical care services in the People's Republic of China." In Rural health in the People's Republic of China: Report of a Visit by the Rural Health Systems Delegation, June 1978. Committee on Scholarly Communication with People's Republic of China. Pp. 23-37. Washington, D.C.: Fogarty International Center.

246. Demers, R.Y., R. Altamore, H. Mustin, A. Kleinman and D. Leonardi. "An exploration of the depth and dimensions of illness behavior." Journal of Family Practice 11:1085-1092. 
247. Kleinman, A. "Sickness as cultural semantics: Issues for anthropological medicine and psychiatry." In P. Ahmed and G. Coelho, eds. Toward New Definitions of Health: Psychosocial Dimensions. Pp. 53-66. New York: Plenum Press.

248. Kleinman, A. and L.H. Sung. "Why do indigenous practitioners successfully heal: A follow-up study of indigenous practice in Taiwan." Social Science and Medicine 13B:7-26.

249. Kleinman, A. "Recognition and management of illness problems: Therapeutic recommendations from clinical social science." In Massachusetts General Hospital Reviews for Physicians: Psychiatric Medicine. T.C. Manschreck, ed. Pp. 23-33. New York: Elsevier.

250. Kleinman, A. and D. Mechanic. "Some observations of mental illness and its treatment in the People's Republic of China." Journal of Nervous and Mental Disease 167(5):267-274.

251. Manschreck, T.C. and A. Kleinman. "Psychiatry's identity crisis: A critical rational remedy." General Hospital Psychiatry 1(2):166-173.

252. Kleinman, A. "Concepts and a model for the comparison of medical systems as cultural systems." Social Science and Medicine 12:85-93. Reprinted in The Nation's Health. P.R. Lee, ed. N.Y.: Boyd and Fraser. Reprinted in The Canadian Health Care System, Vol. 1. C. Crichton, ed. Ottawa Canadian Hospital Association, 1983. Reprinted in Concepts of Health, Illness and Disease: A Comparative Perspective. M. Stacey and C. Currer, eds. Warwickshire, U.K.: Berg Publishing, 1986.

253. Kleinman, A., L. Eisenberg, and B. Good. "Culture, illness and care: Clinical lessons from anthropological and cross-cultural research." Annals of Internal Medicine 88:251-258. Reprinted in Handbook of Patient-Provider Interactions: Raising and Responding to Concerns about Life, Illness and Disease. Wayne A. Beach, ed. Pp. 75-85. New York: Hampton Press, 2012.

254. Kleinman, A. "Comparison of traditional and modern practitioner-patient interactions in Taiwan: The cultural construction of clinical reality." In Culture and Healing in Asian Societies. A. Kleinman, P. Kundstadter, E. R. Alexander, and J. C. Gate, eds. Pp. 329-37. Cambridge, MA.: Schenkman.

255. Kleinman, A. "Clinical relevance of anthropological and cross-cultural research: concepts and strategies." American Journal of Psychiatry 135(4):427-431.

256. Kleinman, A. "International health care planning from an ethnomedical perspective: Critique and recommendations for change." Medical Anthropology 2(2):71-96.

257. Kleinman, A. "What kind of model for the anthropology of medical systems?" American Anthropologist 80(3):662-665. 
258. Kleinman, A. and E. Mendelsohn. "Systems of medical knowledge: A comparative approach." Journal of Medicine and Philosophy 3(4):314-330.

259. Kleinman, A. "Native healers." Human Nature 1 (11): 63-69. Reprinted in Emerging China. T. Draper, ed. Pp. 186-194. New York: H.W. Wilson, 1980, under the title "Taiwanese folk medicine." Reprinted in Anthropology: Contemporary Perspectives, third edition. Phillip Whitten, ed. New York: Little, Brown and Company, 1981.

260. Kleinman, A. "Depression, somatization and the new cross-cultural psychiatry." Social Science and Medicine 11(1):3-10.

261. Kleinman, A. "Rethinking the social and cultural context of psychopathology and psychiatric care." In Renewal in Psychiatry. T.C. Manschreck and A. Kleinman, eds. Pp. 97-138. Washington, D.C.: Hemisphere Publishers.

262. Kleinman, A. "Lessons from a clinical approach to medical anthropology." Medical Anthropology Newsletter 8(4):11-15.

263. Kleinman, A. "Cognitive structures of traditional medical systems: Ordering, explaining, and interpreting the human experience of illness." Ethnomedicine 3(1-2):27-49.

264. Kleinman, A. "A comparative cross-cultural model for studying health care in China." Studies in Comparative Communism 7:414-419.

265. Yang, S.L and A. Kleinman. "Immunological aspects of term pregnancy toxemia." American Journal of Obstetrics and Gynecology 122(6):727-731.

266. Kleinman, A. "Social, cultural, and historical themes in the study of medicine and psychiatry in Chinese societies: Problems and prospects for the comparative study of medical systems." In Medicine in Chinese cultures: comparative studies of health care in Chinese and other societies. A. Kleinman et al., eds. Pp. 589-644. Washington, D.C.: U.S. Government Printing Office for Fogarty International Center, National Institutes of Health.

267. Kleinman, A. "The symbolic context of Chinese medicine." American Journal of Chinese Medicine 3:1-25.

268. Kleinman, A. "Cross-cultural studies of illness and health care: A preliminary report." Bulletin of the Chinese Society of Neurology and Psychiatry 1(2):1-5.

269. Kleinman, A. "Medical and psychiatric anthropology and the study of traditional medicine in modern Chinese Culture." Journal of the Institute of Ethnology, Academia Sinica 39:107-123.

270. Kleinman, A. "Explanatory models in health care relationships." In Health of the Family. National Council for International Health. Pp. 159-172. Washington, D.C.: National Council for International Health. 
1973

271. Kleinman, A. "Medicine's symbolic reality: A central problem in the philosophy of medicine." Inquiry 16:206-213.

272. Kleinman, A. "Toward a comparative study of medical systems." Science, Medicine and Man 1:55-65.

273. Kleinman, A. "Some issues for a comparative study of medical healing." International Journal of Social Psychiatry 19(3/4):159-165.

274. Kleinman, A. "The background and development of public health in China: An exploratory essay." In Public Health in the People's Republic of China. M.E. Wegman, T.Y. Lin and E.F. Purcell, eds. Pp. 1-23. New York: Josiah Macy, Jr. Foundation.

1971

275. Yang, S.L., A. Kleinman, E. Rosenberg and P.Y. Wei. "The effect of labor and mode of delivery on immunoglobulin concentrations in the neonate." American Journal of Obstetrics and Gynecology 109:78-81.

1970

276. Yang, S.L. and A. Kleinman. "Quantification of Igm and IgA in umbilical cord sera of Chinese newborns in Taiwan." Southeast Asian Journal of Tropical Medicine and Public Health 1(3):401.

\section{References}

Cohen, A, A Kleinman, and B Saraceno, eds.

2002 World Mental Health Casebook: Social and Mental Health Programs in Low-Income Countries. New York: Kluwer Academic/Plenum Publishers.

Goldsmith, SK, TC Pellmar, AM Kleinman, and WE Bunney, eds.

2002 Reducing Suicide: A National Imperative. Washington, D.C.: The National Academies Press.

Good, B, and A Kleinman, eds.

1995 Culture and Depression. Berkeley: University of California Press.

Kleinman, A

1977a Explaining the efficacy of indigenous therapies: the need for interdisciplinary research. Culture, Medicine and Psychiatry 2: 1-3.

1977b Culture and illness: A question of models. Culture, Medicine and Psychiatry 1(3): 229-231.

1980a Major conceptual and research issues for cultural (anthropological) psychiatry. Culture, Medicine and Psychiatry 4(1): 3-13.

1980b Patients and Healers in the Context of Culture: An Exploration of the Borderland Between Anthropology, Medicine, and Psychiatry. Berkeley: University of California Press. Awarded the Wellcome Medal for Medical Anthropology, 1980, Royal Anthropological Institute. Japanese translation published by Kobundo, Tokyo, Japan.

Kaufman, J, A Kleinman, and A Saich, eds.

2006 AIDS and Social Policy in China. Cambridge: Harvard University Press. 


\section{Kleinman A.}

2006 What Really Matters: Living a Moral Life Amidst Uncertainty and Danger. Oxford University Press. Chinese translations published by Shanghai Joint Publishing Company, Shanghai, P.R. China 2007, and by PsyGarden Publishing Company, Taiwan, 2007; Japanese translation published by Seishin Shobo, Tokyo, 2011.

2014a The Search for Wisdom: Why William James Still Matters. In The Ground Between: Anthropologists Engage Philosophy. V Das, MD Jackson, A Kleinman, and B Singh, eds. Durham, NC: Duke University Press.

2014b How We Endure. The Lancet 383(9912): 119-120.

2015a An Intellectual Journey and Personal Odyssey. Bulletin of the American Academy of Arts and Sciences Spring LXVIII(3): 58-59.

2015b Care: in search of a health agenda. The Lancet 386: 240-241.

Manschreck, T, and A Kleinman, eds.

1977 Renewal in Psychiatry. Washington, DC: Hemisphere Publishers, Halsted Press.

Petryna, A, A Lakoff, and A Kleinman, eds.

2006 Global Pharmaceuticals: Ethics, Markets, Practices. Durham, NC: Duke University Press.

Yang, SL, and A Kleinman

1970 Quantification of Igm and IgA in umbilical cord sera of Chinese newborns in Taiwan. Southeast Asian Journal of Tropical Medicine and Public Health 1(3): 401.

1974 Immunological aspects of term pregnancy toxemia. American Journal of Obstetrics and Gynecology 122(6): 727-731.

Yang, SL, A Kleinman, E Rosenberg, and PY Wei

1971 The effect of labor and mode of delivery on immunoglobulin concentrations in the neonate. Journal of Obstetrics and Gynecology 1(3): 401. 